\title{
Pressure Groups and Rent Capture: How Effective Are Public Employment Policies: The Case of Gabon
}

\author{
Jean Louis Nkoulou Nkoulou ${ }^{1}$ \\ ${ }^{1}$ Member of the Laboratory of Applied Economics, Omar Bongo University, Gabon \\ Correspondence: Jean Louis Nkoulou Nkoulou, Member of the Laboratory of Applied Economics, Omar Bongo \\ University, Gabon. E-mail: nkouloujeanlouis@hotmail.com
}

Received: October 10, 2021

Accepted: February 10, 2022

Online Published: March 2, 2022

doi:10.5539/ijbm.v17n4p17

URL: https://doi.org/10.5539/ijbm.v17n4p17

\begin{abstract}
In developing countries, and more specifically in the franc zone economies, the weight of the public sector seems to be preponderant, both in a situation where the State is a direct actor in the face of pressure groups and in a situation where it is an arbitrator between pressure groups.

From a theoretical model supported by an empirical verification, whose assumptions are based on the Gabonese economy, we wanted to know in what terms this problem arises in a rent economy in which the State has a strong hold on all economic and social levers.

The lessons learned from the model indicate that the explanation for this state hegemony lies in a deliberate weakening of the bargaining power of pressure group leaders through the lever of corruption. It turns out that the impact of such a choice of public policies is still harmful to unemployment, economic growth and poverty. Moreover, the game between the State and the unions in Gabon generates unstable economic balances as long as the structural reforms of the Gabonese economy remain embryonic in an increasingly open world. All of which worsens the state of poverty in this small country, which is nevertheless endowed with potential wealth.
\end{abstract}

Keywords: public services, pressure group, political rent, unstable balance, public policy, strategy

\section{Introduction}

The recent questioning of the role of the State in the implementation of public policies (Baruch \& Bezes, 2006; Maury, 2014), revealed by the evidence of diminishing returns to State interventions, on the one hand (Fauroux \& Splitz, 2004), and by the asymmetries of information of which it is a victim on the other hand, combined with the harmful role played by pressure groups that from lobbying secret the capture of power and corruption in the public sector (Laffont \& Tirole, 1991, Lavallee et al., 2010). So many fairs that militate not only for the reduction of the size of the public sector within the economy (Mengue, 2013), but especially leads to the revision of the nature of the links that the State maintains with the intermediary bodies, especially the organizations of pressure groups (Lambert, 1990; Mouriaux, 2013).

A pressure group or interest group is a more or less well organised social group that exerts pressure on public authorities in order to defend its particular interests, whether economic or not. Its modes of action can be discrete (lobbying, participation in consultative bodies, activation of networks and corruption), while the sector is perceived as a set of institutions aiming to improve collective well-being (Dufour et al., 2013; Cazabon-Sansfaçon, Tremblay, \& Hatch, 2019).

Rent capture is a corruption of_authority that occurs when a political entity, legislator, or regulator is co-opted to serve the commercial, ideological, or political interests of a minor member, such as a geographic area, industry, profession, or ideological group (Michael Boyle, 2021)

Thus, the relationship between the public sector and pressure groups (Siwek-Pouydesseau, 2004), which often takes the form of a bilateral monopoly (Williamson, 1979), (Note 1) is the source of many theoretical debates in public policy analysis.

Thus, it seems possible to retain three reading grids devoted to research between pressure groups and public authorities. The first presents the State, which embodies the public sector, and the pressure groups as institutions that constitute substitutes for the market, whose aim is to compensate for the lack of coordination of exchanges 
on the market through a bilateral negotiation process (Lesueur \& Sabatier, 2008). Secondly, these institutions serve to frame this market through the development of rights that specify the legal conditions of exchange. However, this grid has the disadvantage of assimilating institutions as exogenous collective entities, which violates the principle of individualism. To endogenize the role of institutions, game theory is used (Walliser, 2003) (Note 2).

The second analytical grid addresses the question of the link between pressure groups and the State from the strategic behaviours of the actors (Labbé \& Nezosi, 2007; Behrend \& Hipp, 2017). In this regard, this relationship will depend on the very typology of pressure groups which around two essential and non-exclusive visions (Deschodt jean pierre et al., 2010; Béroud, Chartier, Dupuy, Kahmann, \& Yon, 2018). The first vision, embodied by the socio-economic order, leads to a distinction between revolutionary pressure groups that aim to make the State disappear and retain confrontation as the dominant strategy, and reformist pressure groups that seek to improve the functioning of the State and thus favour negotiation as a management method (Guillaume \& Mairet, 2004).

The last analytical grid is based on the analysis of impure public goods to examine the relationship between pressure groups and the State (Greffe, 2009). According to this approach, pressure groups produce an impure public good, namely a club good. The main action of pressure groups is then to promote a redistribution of income in favour of their members and not to encourage the government to reach the Pareto optimum (Olson, 2004). This attitude generally explains the appearance of social conflicts which force the State to use negotiation or even legitimate constraint to promote social peace (Béroud, Dupuy, Kahmann, \& Yon, 2019).

All in all, these theoretical debates underline complementary and competing logics in the analysis of the links between the state (representing the public sector) and pressure groups (Note 3) in the process of capturing power and therefore public sector rents. It seems appropriate then to see in what terms this debate arises in Gabon for at least two obvious reasons:

1) The Gabonese economy is in the hands of the public sector, which is more than $50 \%$ state-owned and employs on average more than half of the employees of the Gabonese economy. The public sector is therefore highly unionized, representing the interests of public agents in the sharing of the rent, due in particular to the lack of transparency in the remuneration policy and administrative promotions;

$2^{\circ}$ ) In Gabon, the public authorities are stakeholders in the negotiations between employers (business leaders) and private sector trade unions through collective agreements, on the one hand, and between the State itself and public sector employees, on the other.

$3^{\circ}$ ) Gabon's economy is driven by commodity rents, which are captured not on the basis of merit (i.e. marginal productivity), but according to the proximity of the agents to the political rent (Ondo Ossa, 2011).

In this context, the links between the state and pressure groups depend on the mode of governance (Grelley P., 2012). First, these links can be a manifestation of a conflict situation where each actor elaborates a strategy to increase gain. Secondly, these links can constitute a means of conflict resolution, and the State then plays the role of the arbitrator to ensure and guarantee an equitable sharing.

The intuition that the Gabonese economy is a cash economy in which there is a duality in the modes of remuneration between the public and private sectors, and where corruption reigns (Ondo Ossa 2011), on the one hand, and the conviction that there is a problem of rent sharing in the public sector between the state (actor) and the central trade union CONASYSEP (Confederation of Public Sector Trade Unions), on the other. Similarly, the State acts as a mediator in the negotiation of collective agreements between private sector workers and employers. All these facts suggest a dual interpretation (non-cooperation and cooperation) of the links between the state and pressure groups in Gabon.

The purpose of this paper is to appreciate, from a theoretical and empirical analysis, the stakes of the links between the State and the trade unions, in situations of non-cooperation and in situations of cooperation. We would like to show the State and the unions as a manifestation of conflict situations (part 1), before analysing the State as a means of conflict resolution for the unions.

\section{Theoretical Analysis of Rent Capture and Inefficiency of Public Policies in Gabon}

This analysis will be made in turn from a situation of non-cooperation between the State and pressure groups, and in a situation where the State is in cooperation with pressure groups.

\subsection{Rent Capture in A Situation of Non-Cooperation between Pressure Groups and the State}

The aim is to assess the impact of the behaviour of public agents on the functioning of public employment 
policies conducted by the government in a configuration where the cross-interests of the actors are largely assumed. To do this, we are led to define the analytical framework which allows us to focus on the data of the framework and the hypotheses of the model before examining the articulations and the implication of the model in the form of a strategic game.

\section{A: Framework for Analysis}

This framework is defined based on the related data and the assumptions that follow.

\subsubsection{The Data}

1) we are on the labour market

2) The analysis of the links between the state and pressure groups in Gabon takes the form of a bilateral monopoly, with the state being the only employer in the public sector (due to the strong centralisation of the state linked to the absence of a real decentralisation policy), while the central trade union Conasysep (union syndicale des agents publics) is the main organisation for the supply of labour to public agents;

3 ) it is about negotiation links and therefore about contracts;

4) we have two groups of pressures on the labour market in Gabon, the public sector unions which have direct links with the State, on the one hand, and the private sector unions which have indirect links with the State, on the other.

\subsubsection{Assumptions}

1) the negotiation between the State and the trade union centre concerns a single object, the income;

2) here the State negotiates for the maintenance, if not the increase of its rent (b), and the trade union negotiates the cost that it will have to undergo in terms of the well-being of its members (c);

3) The State knows all the parameters of the union (degree of resistance, its attraction for the present, its reservation wage...), the union does not know the type of interlocutor with which it deals. It only knows the static distribution of the parameter $\mathrm{b}$, assumed to conform to a continuous distribution function $\mathrm{F}(\mathrm{b}, \bar{b})$

4) the negotiation takes place over two periods.

For simplicity's sake, only the uninformed agent (union) is entitled to make offers.

At the beginning of the negotiations, the union proposes a salary $w_{-} 1$ If the State accepts, the negotiation stops, if it refuses, the union proposes a second and final offer $w_{2}$ If it refuses, the union makes a second and final offer, which can be accepted or refused by the state.

Let us express the utilities of the two agents (state and union) in monetary equivalents, i.e.:

$$
\begin{array}{ll}
w_{1}-c, b-w_{1} & \text { (1) if the first offer is accepted, } \\
\delta_{s}\left(w_{2}-c\right), \delta_{e}\left(b-w_{2}\right) & \text { (2) if the second offer is accepted, }
\end{array}
$$

and, $(0,0),(3)$ in case of failure.

With: $\delta_{s}$ and $\delta_{e}$ the respective discount rates of the union and the State.

If $\delta_{e}<\delta_{s}$ then :

$$
w_{1}=w_{2}=w_{m}
$$

with, $w_{-} m$ the average wage between two periods. This relationship is a Bayesian Nash equilibrium.

In other words, the state accepts the first union proposal in the first period, and there is no more negotiation in period 2. This suggests that the negotiated good (the wage) is a durable good, the relation (4) indicates that the optimal strategy of the union is to propose high wages that it announces once and for all, with the consequence of no longer negotiating it.

We rule out such possibilities since wages are an indicator of the well-being of economic agents. However, well-being fluctuates according to imponderables that must be taken into account (Stokey, 1980).

\section{B: Articulation and implication of the model}

We focus on the game that leads to the search for perfect Bayesian equilibria which are obtained by the regressive recurrence method (Kuhn) due to the fact that the negotiations are spread over time.

The principle of the game is to start with the final situations on the decision tree, i.e. those where the State has the choice between accepting or rejecting the union's last offer $w_{2}$. The optimal strategy of the State is obviously to 
accept this offer if $w_{2}<b$ and to refuse if $w_{2}>b$.

By going up one level in the decision tree, it is possible to calculate the optimal union offer in the second period, conditional on the refusal of its offer in the first period.

To do this, the union must take into account the wage anticipation function of the state, noted $w_{2}\left(w_{1}\right)$.

The State accepts in the first period if and only if:

$$
b-w_{1} \geq \delta_{e}\left(b-w_{2}\left(w_{1}\right)\right)
$$

That is, if:

$$
b \geq \alpha\left(w_{1}\right)=\frac{w_{1}-\delta_{e}\left(w_{1}\right)}{1-\delta_{e}}
$$

The probability that the salary $w_{2}$ is accepted knowing that $w_{1}$ was refused is therefore $1-\frac{F\left(w_{2}\right)}{F\left(\alpha\left(w_{1}\right)\right)}$ the expected profit for the second period is:

$$
B_{2}=\left(w_{2}-c\right)\left(F\left(\alpha\left(w_{1}\right)\right)-F\left(w_{2}\right)\right)
$$

Since expectations are rational, the optimal rent expected by the state in the second period is:

$\mathrm{s} / \mathrm{c}: w_{2}$

$$
B * 2(w 1)=\operatorname{Max}\left(w_{2}-c\right)\left(F\left(\alpha\left(w_{1}\right)\right)-F\left(w_{2}\right)\right)
$$

In choosing its offer for the first period, the syndicate must take into account the State's expectations in terms of expected income. The syndicate's first period bid is therefore made in such a way that:

$w *_{1}$ is the optimal solution of a free maximization (Note 4) of :

$$
\operatorname{Max}\left\{\left(w_{1}-c\right)\left(1-F\left(\alpha\left(w_{1}\right)\right)\right)+\delta_{s} B *_{2}\left(w_{1}\right)\right\}
$$

Conditions (6), (7) and (8) characterize the equilibrium of the sequential game that exists when the expectation function $\alpha($.$) is continuous, or what is equivalent, when the state's rent { }_{2}$ is a strictly concave function of $p_{2}$. We can then deduce that there is always a solution to this game even in the case where the number of trading periods is greater than 2. In other words, for any $\mathrm{T}$, there is a unique equilibrium of the sequential game with $\mathrm{T}$ periods.

Assuming that the number of periods $\mathrm{T}$ is fixed at 2, and assuming that the union's costs are zero, on the one hand, and that the state rent is uniformly distributed over the periods $\mathrm{T}$, with $\mathrm{T}$ belonging to $(0,1)$.

While it is true that there is a single equilibrium in this game, the situation is complicated by the uncertainty generated by taking into account the discount rate, which in reality reflects the degree of impatience of unionists over T periods.

In other words, we have the following relationships:

$$
\begin{aligned}
& \delta_{s}=\delta<1 \\
& \delta_{e}=1
\end{aligned}
$$

The relation (10) confirms the hypothesis according to which, the trade union has incomplete information, which justifies the degree of impatience of the trade unionists (Note 5). Relation (11), on the other hand, shows that the state has perfect information about the negotiations. The only unknown in this game is the degree of patience of the union.

The balance of this game is therefore defined by the weight of $\delta$ and especially its financial impact on the state's income.

By doing a free maximization of the relation (9) it comes that:

$$
\begin{aligned}
& w *_{1}(\delta)=\frac{(2-\delta)^{2}}{2(3-2 \delta)} \\
& w *_{2}(\delta)=\frac{(2-\delta)}{2(3-2 \delta)}, \\
& \alpha *(\delta)=\frac{(2-\delta)}{(3-2 \delta)}
\end{aligned}
$$


Three outcomes are then possible given the degree of impatience of the unions as measured by $\delta$ In other words, it is a question of multiple equilibria, which are presented as follows:

1) $0, w_{2}^{*}(\delta)$;

2) $(\delta), \alpha^{*}(\delta)$

3) $\alpha *(\delta), 1$

The realization of one of the outcomes depends on the behaviour of the members of the trade union Center. This behaviour is dictated by essentially heterogeneous interests. The first, and weakest, divide is the distinction between the interests of middle-ranking staff and those of professional and managerial staff (who are not very vulnerable) belonging to the same trade union center. The second divide stems from the unions' positions vis-à-vis the State. On the one hand, there are the conformist unions (Note 6) which are prepared to accept the salaries of the second tranche paid at the price of $w *_{2}(\delta)$ On the other hand, there are the protest unions, which are aiming at the third salary tranche, paid at the price of $w *_{1}(\delta)$. The salaries belonging to the first tranche are incomes below the minimum wage and are not subject to negotiation.

The interesting phenomenon, in the case of Gabon (Note 7), is highlighted when $\delta$ decreases. It is expected that the bargaining power of the union will increase, and therefore the state's rent will decrease. Being in a game where it has complete information about the union, the state uses the division of the union as a dominant strategy to preserve its rent. And to do this, it exploits its informational advantage by encouraging the formation of coalitions in which pressure groups with a high degree of impatience ( $\delta$ is high). To this end, the state uses two complementary levers.

The first lever, aimed at vulnerable public servants, consists in multiplying the rounds of negotiation in an environment of poverty, the State aims in fact at coalescing as much as possible the union members with a high propensity of impatience to agree to an increase in income which would be fixed at the level of the second bracket $\left[w_{2}^{*}(\delta), \alpha^{*}(\delta)\left[\right.\right.$ below the union's desired wage $\left(w_{1}\right)$.

The second lever, aimed at the union's elites, consists of practising the corruption of executives through, in particular, the policy of personalised gifts and arbitrary social and administrative promotions. This behaviour of the Gabonese State is at the origin, on the one hand, of the eviction of competent agents and executives in the public administration who either go elsewhere in the private sector or expatriate, or turn to self-employment to develop their know-how, and, on the other hand, of the emergence of a public administration embodied essentially by agents recruited on the basis of sectarian, clan and political clientelism and therefore necessarily incompetent. This reinforces the ineffectiveness of public policies for employment.

In sum, it appears that the game in which the State is in a bilateral relationship with the unions, in a situation of incomplete information, leads to multiple equilibria that are sources of economic inefficiency.

This configuration leads us to believe that it is a zero-sum game, and the only solution to get out of this vicious circle is to increase total wealth by restructuring the economy. In other words, to move from a strong dependence on political rents to a labour market capable of stimulating activities that create added value and where dynamic and competitive economic forces are released to generate jobs and income, while facilitating insertion into international trade.

It is a question of promoting credible public development policies, and more specifically employment policies. In the case of the Gabonese economy, at least two conditions seem necessary. The one linked to the development of the private sector (ONDO OSSA, 2005), on the one hand, and the one attached to the reduction of the size of the State (MENGUE BIDZO, 2013), on the other hand.

The first constraint stems from the strong assumption that the private sector is an essential pillar for boosting economic growth and, by the same token, the emergence of an employer class distinct from the State, with which the unions will engage in direct negotiations with a view to improving working and living conditions. The second requirement is to reduce the role of the State in the economy, by giving it the role of accompanying the (Note 8) improvement of the business environment in Gabon.

It is then necessary to examine in what terms this game is played, this time with three actors in an environment of incomplete information but in a situation of cooperation between the pressure groups and the State.

\subsection{Rent Capture in a Situation of Cooperation between Pressure Groups and the State as Arbiter}

The second is to assess the government's public policy in a context where the state has become an agent for resolving conflicts between antagonistic pressure groups in the labour market. 
It is therefore appropriate to present the three-player negotiation model before proceeding to its interpretation.

\subsubsection{The Model}

The model we develop comes from the work of Fudenberg and Tirole (1983), and adapted by Myerson (1986) to the problem of arbitrage in negotiation.

Its purpose is to define a focus point that is an optimal outcome of the sequential game with incomplete information, in the presence of three players.

\subsubsection{The Assumptions of the Game}

$\mathrm{H} 1$ : the game has three players whose short- or long-term interests are in conflict and may even be in conflict with an effective solution. These are the state, the employers and the trade unions;

H2: Environmental factors related to players' past behaviors are sources of uncertainty and distrust;

H3: State intervention is outside the game;

H4: there are objective criteria of balance and optimality that guide the decisions of the State;

H5: One of the players, called the principal, may have the power to introduce a focus point by means of a pre-game intervention;

H6: There is negotiation between management and labour. Our hypotheses indicate that this is a dynamic game with incomplete information, and the formalism generally adapted to such phenomena is that of Bayesian equilibria (Harysany, 1967; 1968), which are based on beliefs. We assume in this regard that each player i is characterized by: a set $T_{i}$ of possible types of this player; a set of $S_{i}$ of strategies; a Morgenstern-Von Neumann type utility function $u_{i}$; a set of conditional probability functions $p_{i}\left(/ t_{i}\right)$ defined, for any $t_{i} \in T$ on the product set of the other players' types. These data constitute the set of public information i.e. common to all players. The existence of public information suggests that there may be $\mathrm{n}$ utility functions. Thus, we distinguish:

$$
u_{i}=S * T \text {, }
$$

The relation (13) is defined as an a priori utility function of player i before he knows his type and is referred to as an a priori optimum (Note 9).

$$
\check{u}_{i}=S * \widehat{T} l,
$$

This is the utility function of a player knowing his type and is referred to as the interim utility of player i which leads to an interim optimum (Note 10).

$$
\ddot{u}_{\iota}=S .
$$

The function (15) expresses the utility of the mediator, which is external to the game, and thus depends only on the players' strategies.

\section{B: The implications of the game}

Specifically, the analysis of the game from the mediator's point of view concerns the decision rule, also called mechanism, which determines the strategies. In fact, for the mediator, it is a question of determining a rule allowing to define in a random way the strategies of the players according to their type, which supposes his neutrality.

A State mechanism or decision is a function $\varphi$ which, to any $t=t_{-} 1+t_{-} 2$ associates a probability distribution on S. It appears then that the mediator can only influence the choice of the players' strategies, but cannot modify their type.

In fact, there is a moral hazard problem that mediation can only solve by setting up incentive mechanisms. In other words, in order to make the negotiations progress, the mediator must imagine decisions or mechanisms that encourage the unions and the employers to be honest and therefore to reveal all the strategies to him.

A mechanism is then compatible with the incentive if it is set up by the State (ombudsman) which has direct and confidential access to each player in such a way that each one is encouraged to reveal his type honestly and to respect the recommendations of the ombudsman.

Given then an incentive mechanism $\varphi$ and a player is of type $t_{i}$ then the other players are of type $\hat{t}_{i}$ then we can write that :

$$
\varphi(t)=\left(\hat{t}_{i}, t_{i}\right)
$$


with $\varphi(t)$ a probability distribution on $\mathrm{S}$.

The relation (16) indicates that the mediator has all the strategies of all the players at his disposal, and consequently the incentive mechanisms he puts in place are necessarily efficient. The problem then lies in the weight that each player attributes to himself compared to the other. The utility of each player then becomes conditional.

If $p_{i}\left(\hat{t}_{i} / t_{i}\right)$ is the probability that the player in question assigns to the event, then the utility associated with this state is : $\left.p_{i}\left(\hat{t}_{i} / t_{i}\right) \tilde{u}_{i}(\varphi t), \hat{t}_{i}\right)$.

By summing all the players' types, we obtain the total expectation of player i of type $t_{i}$ associated with $\varphi$ :

$$
\left.U_{i}\left(\varphi / t_{i}\right)=\sum_{\hat{t}_{i} \in \widehat{T i}} p_{i}\left(\hat{t}_{i} / t_{i}\right) \tilde{u}_{i}(\varphi t), \hat{t}_{i}\right)
$$

We can now derive the notion of interim optimality for incentive-compatible mechanisms. Specifically, an incentive-compatible mechanism will be said to be $\varphi$ is optimal (or efficient) only if there is no mechanism $\varepsilon$ such that :

$$
U_{i}\left(\varepsilon / t_{i}\right) \geq U_{i}\left(\varphi / t_{i}\right)
$$

It then becomes clear that an incentive-compatible mechanism is precarious and may even lead to suboptimal situations, as the incentive constraints governing these mechanisms become less obvious once all preferences are revealed.

In this configuration, the fairness of the mediator does not imply that arbitration and negotiation are completely equivalent. It is necessary to assume that the players negotiate in an indistinguishable way, i.e. without revealing their private information during the negotiation, otherwise the other players can draw some information on his type and use it to his detriment. Any inter-type compromise leads to a precarious and therefore unstable equilibrium.

One way to solve this problem is to devise an incentive mechanism that is optimal for all possible types of negotiators, and that is defined by an independent mediator who is unanimously agreed upon.

Two important lessons can be drawn from this model. The first stems from the fact that $\varepsilon$ is a parameter that depends on the beliefs of the actors, which leads us to believe that sectoral negotiations have a greater chance of leading to a relatively stable equilibrium than global negotiations, because of the size effect. Thus, the unions, given the specificity of the labour market, have an interest in proceeding with sectoral negotiations for a better improvement of the expected gain. Such an option is only possible if the labour market becomes flexible.

The second lesson is that a mediator in modern economies can only be the state. The public authority is thus presented as a lever for resolving conflicts between trade unions, more precisely between employees' unions and employers' unions. Such a hypothesis is only realistic if we are in the presence of a credible State that gives guarantees of impartiality and transparency to the negotiators.

However, in the case of Gabon, this credibility is compromised by the incestuous links between the employers and the public authorities. Indeed, any company created in Gabon, and which resists, is an ex-growth of the public sector, and therefore benefits from passes and favours from a public authority (Ondo, 2009). Consequently, we witness in this country fruitless negotiations between the unions and the employers. Thus, the objective function of companies is no longer profit maximization, since Gabon has a rent economy, but rather the capture of rent in connection with the public sector, in order to distribute it to the lobbies that ensure their survival.

Therefore, even in a situation of cooperation between pressure groups and the state

\section{Research Methodology}

At the end of this theoretical analysis, the weight of the State seems preponderant, as much in a situation where it is a direct actor in front of the trade unions as in the one where it is an arbitrator between employees' trade unions and the employers. If the explanation of this hegemony of the State is a deliberate weakening of the bargaining power of trade unions, its impact on the labour market remains harmful in terms of unemployment as long as the interplay between the State and trade unions in Gabon generates unstable equilibria.

It is then necessary to see, on an empirical level, the stakes of this capture of the rent between the various actors through an econometric model.

\subsection{The Model}

The purpose of the model is to assess the stakes of the rent capture game between pressure groups and the State, and more specifically how the corruption generated by rent sharing weakens public development policies. This model is drawn from the work of Lavallée et alii (2010) and Sourice (2015), but adapted to the Gabonese context. 
a: the variables of the model

This involves looking at the explained variable and the explanatory variables in turn.

a1: Variable explained

The objective of this model is twofold, to try to explain behaviour in the face of pressure groups and to identify the factors to be accepted associated with being a victim of corruption. Also, the variable explained is Ipc which refers to the quality of policies and institutions. It is measured by the score of the institutional assessment and the country assessments of the World Bank and the Paris Club on corruption.

This choice is based on the conviction that the low quality of policies and institutions linked to the lobbying of pressure groups (Note 11) is an explanatory factor for the inefficiency of employment policies in Gabon.

a2: explanatory variables

The explanatory variables are the factors that influence the behaviour and attitude of citizens in a situation of interaction with the administration. We have identified five explanatory variables.

1- The variable $\boldsymbol{P I}$ refers to the poverty index

2- $\quad$ The variable Unemployment refers to the unemployment rate

3- The variable Tactive denotes the asset rate (or employment rate)

4- Gender (captured by female rate and male rate)

5- Education (captured by persons enrolled in higher education (NSUP)

The specified model has the following functional form:

$$
\text { Ipc }=f(\text { ip, tchômage, } \text { tactif }, \text { genre, } \text { Nsup })
$$

b: the model for estimation purposes

The model for estimation purposes is in linear form as follows:

$$
I p c_{t}=\alpha_{0}+\alpha_{1} \text { Ipc }_{t}+\alpha_{2} \text { Tchômage }_{t}+\alpha_{3} \text { Tactif }_{t}+\alpha_{4} \text { Genre }_{t}+\alpha_{5} \text { Nsup }_{t}+\varepsilon_{t}
$$

With

Tt: time;

$\varepsilon$ the error term;

$\alpha_{0}$ the constant.

\subsection{The Model Data and Estimation}

The data used are from the Afrobarometer database, the estimation period is from 2000 to 2020, i.e. 20 years. Also, due to the low number of observations, we have to quarterlyize the annual data with the Denton method (1971).

At the end of the various preliminary tests, to ensure the absence of the problems of multi-colinearity and auto-regression of the variables resulting from the time series but also the test of cointegration, we proceeded to the estimation of the model.

Despite the existence of a cointegrating relationship between the variables, the fact of having proceeded to a modification of the data (quarterlyization) runs the risk of long term endogeneity. Therefore, we opted for the method of estimation of the modified least squares (FM) whose results are as follows: 


\section{The Results and Discussion}

4.1 The Results

\begin{tabular}{|c|c|c|c|c|}
\hline \multicolumn{5}{|c|}{ Dependent Variable: D(CPI) } \\
\hline \multicolumn{5}{|c|}{ Method: Fully Modified Least Squares (FMOLS) } \\
\hline \multicolumn{5}{|c|}{ Date: $05 / 25 / 21$ Time: $20: 34$} \\
\hline \multicolumn{5}{|c|}{ Sample (adjusted): 2000Q3 2020Q4 } \\
\hline \multicolumn{5}{|c|}{ Included observations: 82 after adjustments } \\
\hline \multicolumn{5}{|c|}{ Cointegrating equation deterministics: C @TREND } \\
\hline \multicolumn{5}{|c|}{ Long-run covariance estimate (Bartlett kernel, Newey-West fixed bandwidth $=4.0000$ ) } \\
\hline Variable & Coefficient & Std. Error & $\mathrm{t}$-Statistic & Prob. \\
\hline $\mathrm{D}(\mathrm{IP})$ & -0.025745 & 0.002558 & -10.06583 & 0.0000 \\
\hline D(WOMAN) & 0.261997 & 0.058254 & 4.497511 & 0.0000 \\
\hline $\mathrm{D}(\mathrm{MEN})$ & -0.188656 & 0.042538 & -4.434987 & 0.0000 \\
\hline D(NSUP) & 0.084938 & 0.035647 & 2.382720 & 0.0200 \\
\hline D(TACTIVE) & -0.012975 & 0.034864 & -0.372159 & 0.7109 \\
\hline D(TCHOMAGE) & 0.004922 & 0.002893 & 1.701191 & 0.0935 \\
\hline CPI(-1) & -0.161739 & 0.048554 & -3.331087 & 0.0014 \\
\hline IP(-1) & -0.004200 & 0.002282 & -1.839940 & 0.0702 \\
\hline WOMAN(-1) & 0.006065 & 0.034406 & 0.176266 & 0.8606 \\
\hline MAN(-1) & -0.009084 & 0.026699 & -0.340239 & 0.7347 \\
\hline NSUP(-1) & -0.009792 & 0.020594 & -0.475478 & 0.6360 \\
\hline TACTIVE(-1) & 0.022816 & 0.019344 & 1.179465 & 0.2424 \\
\hline TCHOMAGE(-1) & 0.000440 & 0.002035 & 0.216370 & 0.8294 \\
\hline $\mathrm{C}$ & -0.000765 & 0.007196 & -0.106288 & 0.9157 \\
\hline @TREND & $4.51 \mathrm{E}-06$ & 0.000165 & 0.027276 & 0.9783 \\
\hline R-squared & 0.998786 & Mean depe & & -0.002855 \\
\hline Adjusted R-squared & 0.998532 & S.D. depen & & 0.464698 \\
\hline S.E. of regression & 0.017805 & Sum squar & & 0.021239 \\
\hline Long-run variance & 0.000116 & & & \\
\hline
\end{tabular}

The results of the model clearly indicate that corruption, generated by pressure groups, is both cyclical and structural in Gabon (the recall force is significant and negative). However, it appears that in the short term the recessionary role of pressure groups on employment policy in Gabon, but in the long term there is hope for a recovery of such effects through a more credible public policy in this sector.

\subsection{Discussion}

Two essential lessons emerge from its results, namely the fight against poverty on the one hand, and the fight against unemployment on the other.

With regard to the first lesson, it appears that the supply of employment in the public sector clearly presents a heterogeneity linked to the relative degree of preference for the present of workers in this sector. Thus, there appears to be a recessionary effect of poverty on corruption, both cyclical and structural. This result suggests that public officials in Gabon have a tolerance for corruption that is accentuated by the nature of the bargaining mechanisms between partners.

In the negotiations between the State and the pressure groups (trade unions), there is an interweaving of two contracts: a contract of delegation between the base of the union (the principal) and the agent (the delegates of the union), and a contract of corruption between the agent and the corrupter (public administration)

The delegation contract is the source of corruption. Through this contract, the principal (the rank and file of the union) delegates bargaining powers to the agent (the union representatives). In the case of Gabon, there are at least two elements that contribute to the emergence of corruption. The first relates to the fact that the task of negotiation affects the rent of the public administration (prestige, financial power and social precedence), but aware of the vulnerability of the agent (union representatives) because of their preference for the present, the public administration will then encourage personal solicitations of the 'agent' in terms of administrative promotion and payment of bribes. The administration thus misappropriates a common good for personal and private purposes. The second element is based on the absence of negotiation rules; the delegates then have a discretionary power 
which unfortunately is guided by personal interests in the absence of sanctions.

The corrupt contract is established between the representatives of the public administration and the representatives of the public employees' union. It is an illicit agreement concerning the misuse of the discretionary power of the union representatives and the sharing of the expected gain. The terms of this sharing will depend on the bargaining power of each party. The agent (shop stewards) and the bribe-taker (representative of the administration) engage in this corruptive relationship as soon as the value of illegality exceeds that of honesty. The value of honesty for the agent (shop steward) depends on two elements. On the one hand, the income that the agent receives from the principal, which in the case of Gabon is unrealistic because the union of public agents does not have the means to pay its representatives. And on the other hand, the probability of being sanctioned, and such a probability is almost nil in the Gabonese situation where the judicial system still has progress to make in terms of its autonomy. For the briber, the decision to initiate a corrupt relationship is linked to the expected gain in monetary terms and the maintenance of his position of prestige.

It is clear that pressure groups (unions) are much more a generator of distortions that accentuate the imperfection of the labour market in Gabon. This imperfection stems from the high degree of tolerance of corruption in the public sector, both at the level of agents and at the level of administrative decision-making centres. This is a situation of bilateral monopoly that places the labour market in a low equilibrium of underemployment, which not only does not allow new entrants to access it, but unfortunately impoverishes public sector workers, thus leading Gabon into a poverty trap.

\section{Conclusion}

Our results suggest that two non-exclusive reforms seem to be important in the Gabonese economy. The first reform should focus on reducing the size of the state, which implies reforming the public sector in order to make public policies more credible. The second should consist of boosting the role of the private sector through proactive policies for retraining public servants in the private sector, on the one hand, and encouraging the spirit of entrepreneurship in young people by implementing training programmes geared towards vocational education and technological innovation, on the other.

\section{Research Limitations}

the main limit of our remainder relating to not taking into account religious and gender factors in the fight against corruption in the administration. and our next article which will focus on the role of young women in improving performance in the public sector.

\section{Recommendations and Suggestions}

Such a configuration can only be viable through a public policy based on at least two complementary actions. The first action would consist in democratizing trade union practice in Gabon by setting up a system for monitoring and sanctioning trade union leaders, on the one hand, and by setting up a mechanism for renewing trade union leaders by means of a membership vote. The second action would be to make the framework of negotiations between the State and the unions transparent in order to avoid any form of bargaining and exploitation of the dominant position on the part of the State. And this transparency can only be guaranteed by the activation of a free investigative press, independent anti-corruption organisations and a free and credible judicial system.

The second lesson concerns the fight against unemployment, particularly youth unemployment, which can be broken down into two complementary areas, namely the promotion of youth entrepreneurship and the generalization of vocational training.

With regard to the promotion of entrepreneurship, public decision-makers should seek to implement a true entrepreneurship ecosystem by instilling an entrepreneurial spirit in young people from their first contact with the educational world. To this end, and in light of successful experiences, three key actions seem plausible. The first one would be to integrate courses on the notion of entrepreneurship through board games for the youngest with the objective of detecting creative potential during the school year, while the second action would be to create entrepreneurship fairs in high schools and colleges, The third action would be to promote incubators in universities or to capitalize on the work of research centers in order to test and support the prototypes of products and services proposed by project leaders who are still students.

With regard to vocational training, the emphasis should be placed on training in high value-added occupations. This implies that the country must first identify the key sectors of sustainable development. 


\section{References}

Baruch, M. O., \& Bezes, P. (2006). Geneology of State reform. Revue Française d'administration publique, 625-633.

Behrend, C., \& Hipp, L. (2017). Young care workers in Germany and ver.di's "Praktisch. Besser. Jetzt" initiative, Mimeo.

Bellemare, G. (2005). Unionism and social movements: a path to renewing theories of unionism and effective union action? Le cas des services de garde. Économie et solidarités, 36(2), 192-218.

Beroud, S. (2018). La politique nationale des syndicats français en direction des jeunes travailleurs: dispositifs et répertoires d'action. In Béroud S., Chartier F., Dupuy C., Kahmann M., Yon K. (Eds.), Jeunes et mouvement syndical: trajectoires d'engagements et stratégies organisationnelle (p. 169-205). Report produced for the CGT within the framework of the Agence d'objectifs de l'Ires.

Beroud. (2019). Jeunes et engagements au travail: une génération asyndicale? Agora débats/jeunesses, 82, 7-25.

Cazabon-Sansfaçon, L. (2019). Ecological transition and trade union action: the role of Quebec unions. Revue interventions économiques, 62.

Deschod, J. P. (2010). Les forces syndicales Françaises.

Dufour, C. (2013). Les mutations de la représentation des salariés en Grand Bretagne.

Fauroux, R., \& Splitz, B. (2004). Reforming or abdicating: The French choice.

Fudenberg, \& Tirole, J. (1983). Sequential bargaining with incomplete information. The review of Economic Studies, 161(2), 221-248.

Greffe, X. (2009). Economie Globale.

Grelley, P., (2009). Les médiations: pratiques et enjeux. Revue Information Sociales, 170, 4-5.

GUILLAUME C. and MAIRET B., (2004), "négociation collective, paritarisme et démocratisation sociale", API, Doc.

Hyrysany, (1968). Games with incomplete Information Played by Bayesian Players. Management Science, 14, 159-183.

Labbe, D., \& Nezosi, G. (2007). La difficile prise en charge par les syndicats français de la cause des "jeunes travailleurs. Revue de l'Ires, 3(99), 91-119.

Laffont, J. J., \& Tirole, J. (1991). The politics of government decision: a theory of regulatory capture. Quantile Journal of Economics.

Lambert, D. C. (1990). L'Etat-providence en question, Economica, Paris.

Lapointe, P. A. (2016). Social dialogue, Relation du trvail et syndycalisme, perspectives historiques et internationales, Ed. PUL, Université de Laval, Canada.

Lesueur and Sabatier. (2008). Microéconomie de l'emploi, Librairie cyrolles.

Mauriaux, R. (2013). Le syndicalisme en France depuis 1945. ed. la découverte.

Maury, S. (2014). la GRH dans la fonction publique. documentation française, p.125.

Mengue Bidzo, M. (2013). Optimal size of the state in a monetary union: the case of CEMAC. Revue d'Economie Appliquée, 1(1).

Mertins-Kirkwood. (2018). Making Decarbonization Work for Workers. Policies for a just transition to a zero-carbon economy in Canada. Canadian Centre for Policy Alternatives.

Michael, B. (2021). Regulatory Capture, Updated Mar 1

Myerson. (1986). Multistage Games with Communication. Econometrica, 54, 323-358.

Olson. (2004). The paradox of union membership: an experimental approach in terms of public good games. Economie et prévision, 164.

ONDO, O. A. (2005). La délégation de la budgétaire : le cas de la CEMAC. Economie et gestion, 4(1), 3-31.

Siwek-Pouydesseau. (nd). The relations of the State-Boss with the civil servants' unions. Revu IRES, 45(2).

Stokey. (1980). Information et transmission in regulated markets. Canadian Journal of Economics, 26(4), $815-829$ 
Walliser, B. (2003). Théorie des jeux et institutions. Cahier d'économie publique, 44, 165-179.

Williamson. (1979). Transaction Cost Economics: The Governance of Contractual Relations. Journal of Law and Economics, 22, 233-261.

\section{Notes}

Note 1. The idea behind this thesis stems from the work of Williamson (1979), which shows in particular that whenever a transaction is recurrent and involves specific investments, a long-term commitment between the preferred partners is preferable to free competition.

Note 2. The first is that game theory is at a higher level of generality than economic theory. The second is that it considers direct relations between actors, and finally, it respects methodological individualism.

Note 3. The logic of confrontation, dominated by the representation of a pressure group against the State, the logic of influence, governed by the representation of a pressure group turned towards the State on which it seeks to influence public choices from the outside, the logic of partnership, underpinned by a situation in which the group enters into dialogue with the State while remaining autonomous, and finally the logic of integration, marked by integration into the State, pressure groups become the structures of the State.

Note 4. The choice of a free maximization reflects the situation in which the rent is known as well as the costs of its implementation, the negotiation becomes then the only one of distribution between the State and the trade union.

Note 5. This impatience in the case of Gabon is also linked to the degree of poverty which reduces the bargaining power of the unions.

Note 6. Because of the favours that such an option confers on Gabon.

Note 7. Gabon is a cash economy, therefore the distribution of wealth does not depend on the productivity of factors, but on the position in relation to power.

Note 8 . This mediation begins with the establishment of a judicial and regulatory framework that encourages private initiative and protects the business community.

Note 9. Here the player has a private information about his type which is false as soon as the information is public.

Note 10. The player can have two types, either he is a leader or a follower.

Note 11. Lobbying and corruption in Africa are two sides of the same coin (B Sourice, 2015).

\section{Copyrights}

Copyright for this article is retained by the author(s), with first publication rights granted to the journal.

This is an open-access article distributed under the terms and conditions of the Creative Commons Attribution license (http://creativecommons.org/licenses/by/4.0/). 